\title{
(5)
}

\author{
AL-DZIKRA \\ Jurnal Studi Ilmu Al-Qur'an Dan Al-Hadits \\ http://ejournal.radenintan.ac.id/index.php/al-dzikra \\ Volume 14, No. 1, Juni Tahun 2020, Halaman 23 - 42 \\ DOI://dx.doi.org/10.24042/al-dzikra.vi4i1.5463
}

\section{Nilai-Nilai Al-Qur'an Dan Pancasila: Sebagai Basis Di Era Revolusi Industri 4.0}

\author{
Endrika Widdia Putri \\ UIN Sunan Kalijaga Yogyakarta \\ endrikawiddiaputri@yahoo.co.id
}

\begin{abstract}
The industrial revolution 4.0 is an era that signifies the sophistication of technology,artificial intelligence, and digital information, facilitating people to improveindustrial effectiveness and efficiency. In its development, however, the industrial revolutionis not consistent withits initial purpose.Having undergone four changes from time to time, it causes a moral decline. Departing from this context, this article seeks to analyze why moral decadence occurs along with the industrial revolution development and how values of the Qur'an and Pancasila contribute to the industrial revolution 4.0. This study is a library research, employing a method of interpretation and data analysis. It argues that moral decline is caused by technology makers and developers with the idea of value-free science. This leads to the encroachment of moral and humanity values.Hence, revitalizing the values of the Qur'an and Pancasila in the context of the industrial revolution 4.0 era is imperativeto establish morality and humanity within its development. The Qur'an and Pancasila, therefore, serves as a moral measurement to its development.
\end{abstract}

\section{Abstrak}


Era revolusi industri 4.0 adalah era yang memanfaatkan kecanggihan teknologi, kecerdasan buatan dan digital untuk menciptakan kondisi yang lebih efektif dan efisien dalam hal perindustrian demi kemudahan bagi manusia. Namun, seiring berkembangnya zaman, perubahan industri tidak lagi berjalan sesuai dengan tujuannya diciptakan. Selain itu, revolusi industri yang telah mengalami empat kali perubahan ini, dari masa ke masa mengalami kemunduran moral. Berangkat dari hal tersebut, penelitian ini akan mengkaji kenapa terjadi kemunduran moral dengan seiring berkembangnya revolusi industri dan bagaimana kontribusi nilai-nilai al-Qur'an dan pancasila terhadap era revolusi industri 4.0. Penelitian ini adalah penelitian kepustakaan dengan menggunakan metode interpretasi dan analisis data sehingga didapatkan suatu kesimpulan. Adapun hasil penelitian ini yaitu kemunduran moral disebabkan oleh para pencipta dan pengembang teknologi itu sendiri yang menciptakan ilmu pengetahuan bebas nilai, sehingga mengantarkan runtuhnya nilai-nilai moral dan kemanusiaan. Menghadirkan nilai-nilai al-Qur'an dan Pancasila di dalam era revolusi industri 4.0 akan menjadikan perkembangannya memiliki moralitas yang tinggi dan manusiawi. Al-Qur'an dan Pancasila akan mengontrol sekaligus menjadi ukuran baik dan buruk dalam perkembangannya.

Kata Kunci: Al-Qur'an, Pancasila, Revolusi Industri 4.0

\section{A. Pendahuluan}

Manusia diberkahi akal oleh Allah swt. yang salah satu fungsinya untuk bisa memikirkan dinamika perkembangan sesuatu agar memberikan kemudahan bagi kelangsungan hidup manusia. Adanya era revolusi industri 4.0 atau disebut pula era digital merupakan tanda keberhasilan manusia dalam memanfaatkan potensi akalnya. Era ini tentunya suatu momentum yang wajib untuk disyukuri. Selain itu, dari era revolusi industri 4.0 ini bisa dilihat bahwa semakin berkembangnya dunia semakin berkembang pula kecanggihan industri yang ditampilkan. Mulai dari fase pertama (1.0) yang ditandai dengan penemuan mesin yang digunakan pada mekanisasi produksi. Fase kedua (2.0) maju selangkah pada etape produksi massal yang memiliki standarisasi dan terintegrasi dengan quality control. Fase ketiga (3.0) lebih maju lagi yang bertumpu pada integrasi komputerisasi secara 
massal. Fase keempat (4.0) hadirnya otomatisasi dan digitalisasi manufaktur dengan perpaduan internet. ${ }^{1}$

Indonesia merupakan salah satu negara yang berdaya saing global melalui percepatan implementasi industri 4.0 dan berkomitmen untuk membangun industri manufaktur. Adanya era revolusi industri 4.0 di satu sisi merupakan keuntungan bagi masyarakat Indonesia. Tapi, di sisi lain keuntungan itu juga merupakan ancaman bagi masyarakat itu sendiri. Dianggap keuntungan karena memberikan kepraktisan hidup, segalanya menjadi serba cepat dan mudah, serta meningkatnya efisiensi dan efektivitas dalam proses perindustrian. Dianggap sebagai ancaman dikarenakan era revolusi 4.0 bagaikan pisau tajam bagi setiap pribadi manusia, apabila ia salah menggunakannya, tidak hanya bisa melukai namun juga mematikan baik bagi diri sendiri maupun orang lain. Dinamika perkembangan era revolusi industri 4.0 jangan sampai lebih banyak mendatangkan petaka ketimbang nikmat. Artinya segala yang terlibat di dalam era revolusi 4.0, baik pencipta, pengembang, pelaku, pengguna, dan teknologinya haruslah berpijak pada aspek moralitas.

Nilai-nilai al-Qur'an dan Pancasila harus dijadikan landasan bagi era revolusi industri 4.0 agar dinamika perkembangannya mendatangkan nikmat dan kemudahan bagi manusia. Pancasila adalah nilai-nilai al-Qur'an dan sekaligus nilainilai yang menyejarah dari masyarakat Indonesia itu sendiri. Antara keduanya saling berkaitan dan mengarahkan manusia kepada jalan yang benar. Sehingga, segala aktivitas era revolusi industri 4.0 haruslah didasarkan pada nilai-nilai universal alQur'an dan Pancasila jika ingin perkembangannya memberikan dampak yang positif, baik bagi negara Indonesia itu sendiri maupun masyarakatnya. Sejatinya, tidak ada yang namanya perkembangan pola pikir manusia yang berdinamika menghasilkan suatu hal yang negatif. Hanya saja, adanya penyebab-penyebab tertentu atau motif-motif tertentu yang membuatnya menjadi tak bermoral. Oleh karena itu, penelitian ini akan mengkaji tentang penyebab kemunduran moral pada era revolusi industri 4.0, dan

1 Hendra Suwardana, "Revolusi Industri 4.0 Berbasis Revolusi Mental," Jurnal Jati Unik, Vol. 1, no. 2 (2017): hlm. 104. dalam http://ojs.unikkediri.ac.id, diakses pada hari Minggu, 30 September 2018, jam 10.15 WIB 
bagaimana kontribusi al-Qur'an dan Pancasila terhadap era revolusi industri 4.0.

Penelitian ini merupakan penelitian kepustakaan (library research) yaitu penelitian yang acuannya menggunakan literatur (kepustakaan) baik berupa catatan, buku, maupun laporan hasil penelitian dari peneliti terdahulu. ${ }^{2}$ Adapun yang menjadi sumber penelitiannya adalah literatur yang terkait dengan al-Qur'an, Pancasila, dan era revolusi industri 4.0 dengan menggunakan metode interpretasi dan analisis. Metode interpretasi yaitu metode untuk menemukan, menuturkan, serta menjelaskan hakikat yang terdapat di dalam objek yang diteliti. ${ }^{3}$ Sedangkan metode analisis yaitu metode untuk merincikan antara definisi yang satu dengan definisi-definisi yang lain, untuk bisa mendapatkan data penelitian. ${ }^{4}$ Langkah awal yang dilakukan dalam penelitian ini adalah mengelompokkan data-data yang ada, khususnya berhubungan dengan yang diteliti, kemudian mendeskripsikan lalu menjelaskan makna yang terdapat di dalam material yang dianalisis berdasarkan fakta dan realitas apa adanya, terakhir penganalisisan data sehingga didapatkan sebuah kesimpulan.

\section{B. Fenomena Era Revolusi Industri 4.0}

Airlangga Hartato Menteri Perindustrian yang diwawancarai oleh situs berita detik.com mengatakan revolusi industri pertama di mulai pada masa Hindia Belanda. Waktu itu, dalam konteks steam engine atau mesin uap revolusi pertama hadir $^{5}$ dengan mekanisasi yang mulai menggantikan pekerjaan manusia pada tahun 1784. Revolusi yang kedua ditandai dengan kegiatan produksi secara masal yang ditenagai oleh listrik dengan mesin-mesin produksi canggih yang muncul pada akhir abad ke19. Kemudian, pada tahun 1970 revolusi yang ketiga ditandai dengan otomasi manufaktur dengan menggunakan teknologi

${ }^{2}$ M. Iqbal Hasan, "Pokok-Pokok Materi Metodologi Penelitian dan Aplikasinya" (Jakarta: Ghalia Indonesia, 2002), hlm. 11.

3 Kaelan, Metodologi Kualitatif Bidang Filsafat (Yogyakarta: Pramadina, 2005), hlm. 148-149.

4 Sudarto, "Metodologi Penelitian Filsafat", Cet. 3 (Jakarta: PT Raja Grafindo Persada, 2002), hlm. 59.

${ }^{5}$ Fadhly Fauzi Rachman, “Apa itu Revolusi Industri”, Artikel, Rabu, 04 April 2018, dalam http://m.detik.com, diakses pada hari Minggu, 30 September 2018, jam 10.10 WIB. 
komputer. ${ }^{6}$ Selanjutnya, era revolusi industri 4.0 adalah era yang ditandai dengan kecerdasan buatan (artificial intelligence), mobil otomatis, super komputer, teknologi nano, rekayasa genetika, dan inovasi. $^{7}$

Istilah industri 4.0 diciptakan pertama kali di Jerman yang ditandai dengan revolusi digital pada tahun 2011. Industri yang dapat meningkatkan produktivitas dengan menggunakan berbagai jenis teknologi yang proses industrinya terhubung secara digital mulai dari $3 D$ printing hingga robotik. ${ }^{8}$ Industri 4.0 memperkenalkan teknologi produksi massal yang fleksibel, yang mana mesin akan beroperasi secara independen atau berkoordinasi dengan manusia. Industri 4.0 menggunakan sebuah pendekatan untuk mengontrol proses produksi dengan melakukan sinkronisasi waktu dengan melakukan penyatuan dan penyesuaian produksi. Selanjutnya, industri 4.0 digunakan pada tiga faktor yang saling terkait yaitu; 1) digitalisasi dan interaksi ekonomi dengan teknik sederhana menuju jaringan ekonomi dengan teknik kompleks; 2) digitalisasi produk dan layanan; dan 3) model pasar baru. ${ }^{9}$

Berdasarkan penjelasan di atas bisa disimpulkan bahwa era revolusi industri 4.0 atau yang disebut juga dengan era revolusi digital adalah era yang memanfaatkan kecanggihan teknologi dan digital untuk menciptakan kondisi yang lebih efektif dan efisien dalam hal perindustrian. Robot kecerdasan buatan (artificial intelligence/al) adalah salah satu hal yang digadang-gadang akan menciptakan kemudahan bagi perindustrian karena ia mampu berperan layaknya manusia. Pemberitaan di televisi-pun akhir-

6 Hoedi Prasetyo dan Wahyudi Sutopo, "Industri 4.0: Telaah Klasifikasi Aspek dan Arah Perkembangan Riset,” J@ti Undip Jurnal Teknik Industri, Januari, Vol. 13, no. 1 (2018): hlm. 17. dalam http://ejournal.undip.ac.id, diakses pada hari Minggu, 30 September 2018, jam 10.40 WIB.

7 Venti Eka Satya, "Strategi Indonesia Menghadapi Industri 4.0," Info Singkat, Mei, Vol. 10, no. 09/1/Puslit, (2018): hlm. 20. dalam http://berkas.dpr.go.id, diakses pada hari Minggu, 30 September 2018, jam 10.20 WIB.

${ }^{8}$ Satya, hlm. 20.

9 Muhammad Yahya, “"Era Industri 4.0: Tantangan dan Peluang Perkembangan Pendidikan Kejuruan Indonesia', Pidato Pengukuhan dalam penerimaan Jabatan Profesor Universita Negeri Makassar," http://eprints.unm.ac.id, 14 Maret 2018, hlm. 4. 
akhir ini banyak membicarakan robot kecerdasan buatan (artificial intelligence/al) yang menggantikan pekerjaan-pekerjaan manusia. Misalnya robot kecerdasan buatan yang membantu proses produksi makanan dan minuman kemasan yang bekerja secara cepat dan konsisten, atau robot kecerdasan buatan yang membantu kegiatan industri tekstil, ataupun produksi kendaraan; mobil, motor dan lain-lainnya, atau robot kecerdasan buatan membantu manusia untuk membawa dan mengangkat bebab-beban berat.

Melihat fenomena yang terjadi sekarang, perkembangan teknologi dan perindustrian lebih banyak mendatangkan petaka ketimbang nikmat. Semakin canggih teknologi yang diciptakan semakin bahaya pula petaka yang datang. Misalnya: pertama, komputer dari zaman ke zaman mengalami perkembangan, semakin canggih komputer semakin canggih pula virus yang diciptakan. Akibatnya, pengguna komputer diharuskan selalu memasang anti virus yang gratis maupun yang berbayar dan bahkan sampai harus sering diinstal, yang hal demikian memakan biaya. Kedua, jaringan internet dari zaman ke zaman juga mengalami perkembangan. Sekarang berada pada jaringan yang tercepat $4 \mathrm{G}$ dan bahkan telah ada yang menggunakan $5 \mathrm{G}$. Kecepatan jaringan $4 \mathrm{G}$ dan $5 \mathrm{G}$ ini lebih cepat dari jaringan sebelumnya. Namun, kecepatan jaringan ini tidak dibarengi dengan ke-hemat-an kuata. Semakin cepat kualitas jaringannya semakin cepat pula kuata menjadi habis. Maka, jika ingin mendapatkan kualitas jaringan tercepat harus siap-siap pula merogoh uang lebih banyak.

Perubahan adalah suatu keperluan bagi manusia, dan itu bukan perkara keinginan manusia itu sendiri tapi juga keinginan Allah swt. yang ingin agar manusia mengalami perubahan. Allah swt. berfirman:

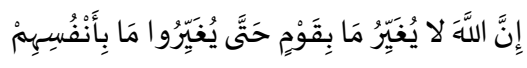

"Sesungguhnya Allah tidak mengubah keadaan sesuatu kaum sehingga mereka mengubah keadaan yang ada pada diri mereka sendiri." (Q.S ar-Ra'd [13]: 11)

Quraish Shihab menafsirkan Q.S. ar-Ra'd [13]: 11 itu terkait dengan perubahan sosial oleh dua pelaku, yaitu Allah swt. dan masyarakat. Perubahan yang dilakukan oleh Allah swt. haruslah didahului oleh perubahan yang dilakukan oleh 
masyarakat dari dalam diri mereka. Tanpa perubahan ini mustahil akan terjadi perubahan sosial. ${ }^{10}$ Artinya, Allah swt. akan membantu manusia untuk berubah, jika manusia itu sendiri yang memulai perubahan. Penafsiran dari Quraish Shihab dinilai relevan untuk menjelaskan bagaimana perubahan sosial itu terjadi yang harus didahului oleh manusia itu sendiri, kemudian Allah swt. memberikan petunjuknya.

Era revolusi industri 4.0 memiliki peranan penting bagi pembangunan ekonomi di semua sektor kehidupan, dan tanggungjawab pemerintah/pemilik industri adalah pemerataan pertumbuhan sebuah industri. Ada beberapa sisi positif yang akan dihasilkan dari era revolusi industri 4.0, pertama, industri mampu memproduksi barang-barang keperluan penduduk setempat dan daerah secara lebih efisien, efektif dan lebih murah. ${ }^{11}$ Kedua, mempermudah mempromosikan hasil kreasi atau industri kepada publik melalui jejaring media sosial untuk mendapatkan tanggapan atau respons sehingga dapat dijadikan ukuran untuk memperbaiki dan meningkatkan kualitas produknya. ${ }^{12}$ Ketiga, mempermudah produksi massal industri. Keempat, terkait dengan penggunaan zatzat kimia pada perindustrian yang berbahaya maka bantuan robot kecerdasan buatan akan sangat membantu.

Selain sisi positif, konsekuensi logis yang harus ditanggung bersama-sama dari perkembangan inovasi dengan terciptanya super-computer, robotic artificial intelegency dan modifikasi genetik, menciptakan dunia yang sangat berbeda dari dunia sebelumnya $^{13}$ yang memiliki sisi negatif yaitu: pertama, adanya kesenjangan yang luar biasa terkait tenaga kerja dari kategori kemampuan skill, yang high skill akan lebih diutamakan dibandingkan low skill. Kedua, ketidakstabilan dunia bisnis karena perubahan yang sangat cepat. Ketiga, munculnya fenomena

10 M. Quraish Shihab, "Tafsir al-Mishbah: Pesan, Kesan dan Keserasian al-Qur'an", vol. 15 (Jakarta: Lentera Hati, 2002), hlm. 233.

11 Suwardana, "Revolusi Industri 4.0 Berbasis Revolusi Mental," hlm. 105.

12 Slamet Rosyadi, "Revolusi Industri 4.0: Peluang dan Tantangan bagi Alumni Universitas Terbuka," http://researchgate.net/publication/, 30 September 2018, hlm. 4.

${ }^{13}$ Suwardana, "Revolusi Industri 4.0 Berbasis Revolusi Mental," hlm. 103. 
robotisasi kemanusiaan. ${ }^{14}$ Keempat, pergeseran budaya terjadi sangat signifikan. Misalnya, kurang tampak lagi budaya gotong royong di kalangan petani, karena adanya mesin proyek industri, yang cukup dilakukan oleh satu atau dua orang saja. ${ }^{15}$

Terkait dengan penyebab terjadinya kemunduran moral pada era revolusi industri 4.0 yaitu pertama, menurut Quraish Shihab adanya pemikiran oleh para pencipta dan pengembang teknologi bahwa ilmu pengetahuan itu bebas nilai, karena itu pula mereka bebas melakukan penelitian dan percobaan walau hal tersebut dapat mengantar kepada runtuhnya nilai-nilai moral dan kemanusiaan. ${ }^{16}$ Kedua, adanya pemikiran bahwasanya kebahagiaan tertinggi berasal dari materi yang menjadikan manusia melakukan apa saja, termasuk cara-cara yang kurang halal agar bisa memperbanyak pundi-pundi keuangannya. Misalnya, pengambilan keuntungan terbesar hanyalah pihak yang memiliki modal dan teknologi. Akibatnya, yang kaya akan semakin kaya. Perkembangan industri bukannya dijadikan batu loncatan untuk membantu kehidupan masyarakat ekonomi kelas bawah serta menciptakan kemaslahatan sosial malah menjadi ketimpangan sosial.

\section{Al-Qur'an dan Pancasila}

Terbentuknya setiap ideologi adalah melalui pengalaman sejarah masyarakat tempat ideologi itu tumbuh. Pancasila sebagai sebuah ideologi merupakan hasil dari sebuah proses sejarah. Dengan kata lain, ideologi Pancasila berasal dari kehidupan masyarakat Indonesia dalam berbangsa dan bernegara yang menyejarah. Pancasila juga merupakan hasil kompromi antara kelompok nasionalis Islam dan nasionalis sekuler. Keduanya muncul dari dua corak reformasi keagamaan. ${ }^{17}$ Secara teori filsafat,

14 Hoedi Prasetyo dan Wahyudi Sutopo, "Perkembangan Keilmuan Teknik Industri Menuju Era Industri 4.0, Seminar dan Konferensi Nasional IDEC 2017," http://idec.industri.ft.uns.ac.id, 30 September 2018, hlm. 493.

${ }^{15}$ Rosyadi, "Makalah "Revolusi Industri 4.0...," hlm. 4.

16 M. Quraish Shihab, "Membumikan al-Qur'an", Jilid. 2 (Jakarta: Lentera Hati, 2012), hlm. 414.

17 Sudaryanto, "Filsafat Politik Pancasila: Refleksi atas Teks Perumusan Pancasila" (Yogyakarta: Kepel Press, 2007), hlm. 144. 
pancasila merupakan hasil pemikiran yang didasarkan kepada nilai-nilai yang hidup dalam masyarakat pada saat sebelum silasila tersebut dirumuskan. ${ }^{18}$ Ada yang mengatakan Pancasila dan alQur'an tidak sejalan. Anggapan ini tentunya kurang tepat. Kebenaran itu adalah satu. Al-Qur'an tidak diragukan lagi kebenarannya (mutlak) karena bersumber dari Allah swt. Sementara Pancasila berasal dari akal pikiran manusia yang sehat. Antara al-Qur'an dan akal tidak mungkin bertentangan. Menurut Muhammad Abduh, wahyu (al-Qur'an) tidak membawa hal-hal yang bertentangan dengan akal, kalau zhahir ayat bertentangan dengan akal haruslah dicari interpretasi sehingga membuat ayat tidak bertentangan dengan pendapat akal. ${ }^{19}$

Pancasila adalah nilai-nilai al-Qur'an, kelima sila dalam pancasila itu sangat Islami sekaligus sesuai dengan karakteristik masyarakat Indonesia yang majemuk. Adapun sila pertama Ketuhanan Yang Maha Esa memiliki makna yaitu segala aspek penyelenggaraan negara harus sesuai dengan nilai-nilai yang berasal dari Tuhan. Baik dalam hal-hal yang bersifat material maupun spiritual. Dalam hal material misalnya bentuk negara, tujuan negara, tertib hukum, sistem negara dan lain sebagainya harus berlandaskan kepada pada Tuhan Yang Esa. Sedangkan dalam hal yang bersifat spiritual yaitu moral negara, moral para penyelenggara negara, moral mayarakat dan lain-lain sebagainya ukuranya adalah nilai-nilai al-Qur'an. ${ }^{20}$ Implikasi sila pertama menjadikan negara Indonesia adalah negara monoteis, sehingga tidak ada agama di Indonesia yang polyteis atau atheis. Seluruh masyarakat Indonesia wajib bertuhan kepada Tuhan Yang Maha Esa (The One).

Adapun makna sila kedua ini adalah pertama, mengakui persamaan derajat, persamaan hak, persamaan kewajiban antara sesama manusia. Kedua, saling mencintai sesama manusia. Ketiga, mengembangkan sikap tenggang rasa. Keempat, tidak semena-

18 Kuntowijoyo, "Demokrasi dan Budaya Birokrasi" (Yogyakarta: Benteng Budaya, 1994), hlm. 3-4.

19 Harun Nasution, "Muhammad Abduh dan Teologi Rasional Mu'tazilah" (Jakarta: UI Press, 1987), hlm. 46-47.

${ }^{20}$ Kaelan, "Filsafat Pancasila" (Yogyakarta: Paradigma, 1996), hlm. 93. 
mena terhadap orang lain. Kelima, menjunjung tinggi nilai-nilai kemanusiaan. Keenam, gemar melakukan kegiatan-kegiatan kemanusiaan. Ketujuh, berani membela kebenaran dan keadilan. Kedelapan, bangsa Indonesia merasa dirinya sebagai bagian dari seluruh umat manusia, karena itu dikembangkan sikap hormatmenghormati dan bekerja sama dengan bangsa lain. ${ }^{21}$

Makna persatuan Indonesia yang merupakan sila ketiga adalah sifat dan keadaan negara Indonesia harus sesuai dengan hakikat satu. Hakikat yang satu itu mutlak tidak dapat dibagi, sehingga bangsa dan negara Indonesia yang menempati suatu wilayah tertentu merupakan suatu negara yang berdiri sendiri, memiliki sifat dan keadaan sendiri yang terpisah dari negara lain di dunia ini. Sehingga negara Indonesia merupakan suatu diri pribadi yang memiliki ciri khas, sifat dan karakter sendiri yang berarti memiliki suatu kesatuan dan tidak terbagi-bagi. ${ }^{22}$ Dari makna tersebut dapat dipahami bahwa adanya kemandirian negara Indonesia untuk mewujudkan persatuan Indonesia tanpa adanya ikut campur tangan negara lain. Selain itu, sila ketiga adalah hakikat dari keberagaman masyarakat Indonesia yang majemuk yang menghendaki adanya rasa saling harga-menghargai dan memiliki di bawah kesatuan nusa, bangsa dan bahasa Indonesia.

Kerakyatan yang dipimpin oleh hikmat kebijaksanaan dalam permusyawaratan dan perwakilan adalah sila keempat dari pancasila. Sila ini memiliki makna yaitu pertama, mengutamakan kepentingan negara dan masyarakat. Kedua, tidak memaksakan kehendak kepada orang lain. Ketiga, mengutamakan musyawarah dalam mengambil keputusan untuk kepentingan bersama. Keempat, musyawarah dilakukan dengan akal yang sehat dan sesuai dengan hati nurani yang luhur. Kelima, keputusan yang diambil harus dapat dipertanggungjawabkan secara moral kepada Tuhan Yang Maha Esa. Keenam, menghargai harkat dan martabat orang lain. ${ }^{23}$

Kemudian sila kelima keadilan sosial bagi seluruh rakyat Indonesia memiliki makna, yaitu: pertama, memaksimalkan tabiat-

${ }^{21}$ Rozikin Daman, "Pancasila: Dasar Falsafah Negara" (Jakarta: PT Raja Grafindo Persada, 1995), hlm. 183-186.

22 "Filsafat Pancasila", hlm. 121.

${ }^{23}$ Daman, "Pancasila: Dasar Falsafah Negara", hlm. 188-189. 
tabiat mulia yang menggambarkan sikap dan suasana kekeluargaan dan kegotong-royongan. Kedua, berlaku adil, menjaga ke-balancean antara hak dan kewajiban serta menghargai hak-hak orang lain. Ketiga, senang menolong orang lain. Keempat, tidak memeras orang lain. Kelima, melakukan hal-hal yang bermanfaat bagi kepentingan umum. Keenam, berusaha bersama-sama menjadikan kemajuan yang berkeadilan sosial dan merata. ${ }^{24}$

Dengan demikian, dapat disimpulkan bahwa pancasila adalah bagian dari al-Qur'an, karena makna dari setiap sila tersebut adalah nilai-nilai al-Qur'an. Jadi, anggapan keliru kiranya jika masih bersikeras bersitegang mengatakan antara pancasila dan al-Qur'an tidak sejalan. Justru ia saling kuat dan menguatkan dan menjadi landasan bagi perilaku keshalehan sosial masyarakat Indonesia.

\section{Nilai-nilai al-Qur'an dan Pancasila sebagai Landasan Moral Era Revolusi Industri 4.0}

Al-Qur'an adalah kitab suci terakhir bagi umat manusia yang diturunkan oleh Allah swt. Al-Qur'an diturunkan bukan untuk umat Islam saja tapi untuk seluruh umat manusia secara universal. ${ }^{25}$ Al-Qur'an merupakan pedoman yang sangat komprehensif untuk umat manusia semenjak munculnya 15 abad yang lalu dan akan tetap sesuai dengan perkembangan zaman pada saat ini maupun untuk masa yang akan datang sampai dengan datangnya hari kiamat nanti. ${ }^{26}$ Selagi manusia masih berpegang pada al-Qur'an yang merupakan kitab sepanjang zaman, maka manusia akan selalu terbimbing untuk berada di jalur kebenaran. Al-Qur'an bukanlah kitab ilmiah, namun al-Qur'an siap diuji keilmiahannya. Semakin al-Qur'an diuji semakin terlihat keilmiahannya, sehingga sampai saat ini tidak ada yang bisa membuktikan bahwasanya al-Qur'an itu tidak ilmiah atau fiksi.

Quraish Shihab dalam bukunya wawasan al-Qur'an mengatakan 'mengulang-ulang membaca ayat al-Qur'an

${ }^{24}$ Daman, hlm. 190-192.

${ }^{25}$ Ulya, "Berbagai Pendekatan dalam Studi al-Qur'an: Penggunaan Ilmu-ilmu Sosial, Humaniora dan Kebahasaan dalam Penafsiran al-Qur'an" (Yogyakarta: Idea Press, 2017), hlm. 1.

26 Wisnu Arya Wardhana, "Al-Qur'an dan Energi Nuklir" (Yogyakarta: Pustaka Pelajar, 2004), hlm. 46. 
menimbulkan penafsiran baru, pengembangan gagasan, dan menambah kesucian jiwa serta kesejahteraan batin. Berulangulang membaca alam raya, membuka tabir rahasianya dan memperluas wawasan serta menambah kesejahteraan lahir." 27 Ini artinya siapa saja yang bersahabat dengan al-Qur'an maka ia akan terarahkan kepada jalan yang akan mendekatkannya pada Tuhan sehingga hidupnya terarahkan dan berjalan lurus di jalurnya, yaitu jalur kebenaran dan kebaikan. Begitu juga dengan bersahabat dengan alam maka ia akan singkapkan ilmunya yang bisa dimanfaatkan manusia untuk mempermudah kebutuhannya. AlQur'an menjadikan sains tidak hanya untuk menemukan kebenaran dalam rangka memenuhi kebutuhan hidup manusia di dunia ini, melainkan lebih jauh daripada itu adalah untuk mencapai keselamatan, ketenangan serta kebahagiaan hidup di balik kehidupan dunia yang fana ini, yaitu kehidupan di akhirat kelak. ${ }^{28}$

Perubahan industri yang telah mengalami empat kali perubahan ini tidak akan terjadi kalau bukan karena Allah swt. yang mengizinkan terjadinya perubahan. Dalam al-Qur'an terdapat ayat-ayat yang berkenaan dengan kalimat "Allah menundukkan" dan yang semakna dengannya, sehingga sebagai manusia seharusnya kita mengambil faedah atas makna ayat tersebut dan tidak membanggakan diri dengan merasa bisa mengendalikan dan menundukkan alam dengan teknologinya, sebab Allah-lah yang menundukkannya. ${ }^{29} \mathrm{Jadi}$, adanya revolusi industri yang telah mengalami empat kali perubahan ini bukanlah semata-mata karena hasil usaha manusia. Namun, Allah-lah yang mengizinkan perkembangan itu terjadi, Allah swt. jugalah yang mempermudah proses perubahan industri tersebut.

Negara Barat adalah negara yang paling hebat dalam perkembangan teknologi dan digital sehingga mereka yang menguasainya. Namun, perkembangan digital tidak ubahnya sebagai alat untuk menambah pundi-pundi kekayaan, dan untuk

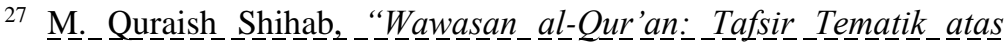

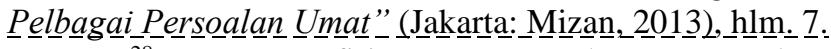

28 Imam Syafi'ie, "Konsep Ilmu Pengetahuan dalam al-Qur'an" (Yogyakarta: UII Press, 2000), hlm. 142.

29 Ahmad Baiquni, "Al-Qur'an dan Ilmu Pengetahuan Kealaman" (Jakarta: Dana Bhakti Prima Yasa, 1996), hlm. 15. 
mendapatkan kekuasaan sebesar-besarnya dalam hal saham. Pembagian hasil yang tidak merata dan tidak sesuai dengan ukuran kerjanya, antara upah dan kerja yang tidak sebanding, yang kaya semakin kaya, sementara yang miskin semakin miskin. Konsep kapitalis masih menjadi musuh besar bagi kalangan buruh. Walaupun mereka bekerja keras sekalipun dan memiliki dedikasi yang tinggi, tidak akan merubah keadaannya sebagai buruh.

Indonesia sebagai negara yang siap menghadapi era revolusi industri 4.0, haruslah mencontoh perkembangan digital dan perindustrian Barat agar terciptanya peradaban yang lebih maju lagi. Namun, jangan sampai perkembangannya sama seperti Barat yang lebih banyak mendatangkan petaka ketimbang nikmat. Perkembangan digital di Indoensia haruslah hanya mendatangkan nikmat. Walaupun pada akhirnya ditemukan hal-hal yang mendatangkan petaka, itu terjadi di luar kehendak manusia. Indonesia yang berideologi Pancasila dan dihuni oleh mayoritas Muslim, haruslah bisa menghadirkan nilai-nilai al-Qur'an dan Pancasila.

Menghadirkan nilai-nilai al-Qur'an dan Pancasila menjadikan perkembangan digital dan industri itu tidak bebas nilai. Ia akan sarat akan nilai dan makna baik nilai etika, moral maupun kemanusiawian. Adapun nilai-nilai al-Qur'an yang bisa dijadikan landasan moral bagi era revolusi indutri 4.0 yaitu:

1. Fokus kepada kebaikan yang bisa dilakukan karena Allah swt. mengetahui apapun yang dikerjakan hamba-Nya. Nilai ini terdapat dalam Q.S. an-Nahl [16]: 19:

$$
\text { وَاللَّهُ يَعْلَمُ مَا تُسِرِّونَ وَمَا تُعْلِنُونَ }
$$

"Dan Allah mengetahui apa yang kamu rahasiakan dan apa yang kamu lahirkan."

2. Umat manusia adalah satu kesatuan yang harus saling mengembangkan sikap hormat-menghormati dan saling berkerja sama, yang mana termaktub dalam Q.S al-Baqarah [2]: 213:

$$
\text { كانَ النَّاسئ أُمَّةً وَاحِدَةً }
$$

"Manusia itu adalah umat yang satu."

3. Berlaku lemah lembut, saling memaafkan dan saling bermusyawarah dalam mengambil keputusan untuk kepentingan 
bersama, serta bertawakkal yang terdapat dalam Q.S. Ali Imran [3]: 159:

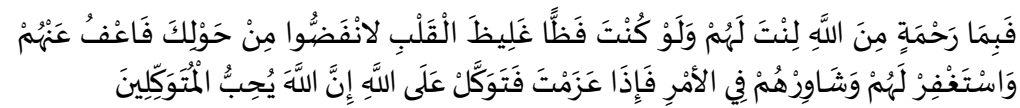
"Maka disebabkan rahmat dari Allah-lah kamu berlaku lemahlembut terhadap mereka. Sekiranya kamu bersikap keras lagi berhati kasar, tentulah mereka menjauhkan diri dari sekelilingmu. Karena itu maafkanlah mereka, mohonkanlah ampun bagi mereka, dan bermusyawarahlah dengan mereka dalam urusan itu. Kemudian apabila kamu telah membulatkan tekad, maka bertawakallah kepada Allah. Sesungguhnya Allah menyukai orang-orang yang bertawakal kepada-Nya."

4. Segala keputusan apapun yang dilakukan di dunia ini akan dipertanggungjawabkan, hal ini terdapat dalam Q.S. al-Isra' [17]: 36:

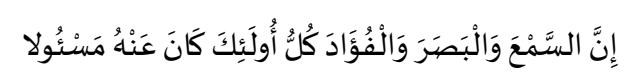

"Sesungguhnya pendengaran, penglihatan dan hati, semuanya itu akan diminta pertanggungan jawabnya."

5. Berlaku adil dan berbuat baik, yang terdapat dalam Q.S. anNahl [16]: 90:

$$
\text { إِنَّ اللَّهَ يَاْْمُرُ بِالْعَدْلِ وَالإحْسَانِ }
$$

"Sesungguhnya Allah menyuruh (kamu) berlaku adil dan berbuat kebajikan."

6. Dilarang bersikap sombong, yang terdapat dalam Q.S. al-A'raf [7]: 146:

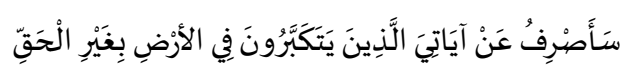

"Aku akan memalingkan orang-orang yang menyombongkan dirinya di muka bumi tanpa alasan yang benar dari tanda-tanda kekuasaan-Ku".

7. Menghargai persamaan hak, persamaan derajat, dan persamaan kewajiban antara sesama manusia, yang termaktub dalam Q.S. al-Hujurat [49]: 13:

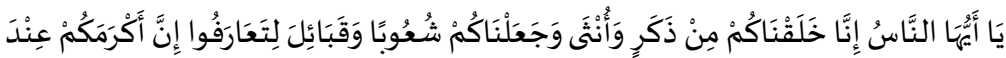

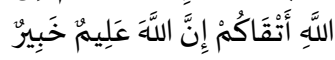

"Hai manusia, sesungguhnya Kami menciptakan kamu dari seorang laki-laki dan seorang perempuan dan menjadikan kamu berbangsa- 
bangsa dan bersuku-suku supaya kamu saling kenal mengenal. Sesungguhnya orang yang paling mulia di antara kamu di sisi Allah ialah orang yang paling bertakwa di antara kamu. Sesungguhnya Allah Maha Mengetahui lagi Maha Mengenal."

Nilai-nilai yang ditampilkan tersebut hanyalah sebagian kecil dari nilai-nilai al-Qur'an yang bisa dijadikan landasan pada era revolusi industri 4.0. Ketika nilai-nilai tersebut bisa dipahami dan diamalkan oleh yang terlibat di dalam era revolusi industri 4.0, maka perkembangan industri di setiap negara umumnya, dan negara Indonesia khususnya akan mengalami perkembangan yang pesat, karena Allah swt. ikut membantu perkembangan itu serta perkembangannya adalah perkembangan yang bermoral dan manusiawi. Lebih jelasnya, segala yang terlibat dalam era digital dan industri, baik pemegang saham, pekerja, mesin dan teknologinya haruslah dihiasi dengan nilai-nilai tersebut serta memunculkan kesadaran akan tujuan perkembangan digital dan industri.

Memahami nilai-nilai al-Qur'an yang ditampilkan di atas akan menyadarkan manusia terhadap beberapa hal. Pertama, Allah swt. selalu mengetahui setiap gerak-gerik hamba-Nya, sehingga ini membuat manusia berpikir panjang untuk melakukan hal-hal yang bertentangan dengan akalnya, dan tentunya ia akan mengarahkan perkembangan teknologi dan digital ke arah yang hanya mendatangkan nikmat. Kedua, tidak membeda-bedakan manusia, karena manusia itu sama, baik derajat, hak dan kewajibannya, yang membedakannya hanyalah kedekatannya pada Tuhan. Hal ini tentunya akan melahirkan sikap saling menghargai antara pekerja industri, yang berimplikasi pada berjalannya dengan positif perkembangan industri tersebut, karena di dalamnya baik keluarannya tentu juga baik. Ketiga, pembagian gaji yang akan merata dan adil, karena pencipta dan pengembang teknologi memahami pentingnya adil sehingga tidak mau memakan hak orang lain. Pembagian gaji yang merata dan adil ini akan berimplikasi pada terciptanya kemaslahatan sosial, dan menurunnya tingkat kemiskinan dan kriminalitas. Keempat, perkembangan teknologi akan berjalan sesuai dengan tujuan teknologi itu diciptakan, yaitu untuk kemudahan umat manusia dan sebagai ladang ibadah menuju kebahagiaan hakiki di akhirat kelak. 
Presiden Indonesia Joko Widodo saat diwawancarai oleh wartawan situs berita detik.com mengatakan bahwa "perlu adanya antisipasi terhadap perubahan-perubahan cepat dunia yang saat ini sudah melanda semua negara. Salah satunya, revolusi industri 4.0 yang perubahannya sudah diprediksi. Untuk itu, kota harus siap dalam menghadapi perubahan ini." ${ }^{30}$ Lebih jelas Bapak Joko Widodo mengatakan bahwa "kita harus sadar betul bahwa akan terjadi perubahan besar yang sangat cepat sekali. Kota juga harus menyiapkan diri dalam mengantisipasi menyiapkan SDM-SDM dalam menghadapi perubahan yang sangat cepat. Saya kira kita tahu semuanya artificial intelligence, big data, kemudian penemuan-penemuan yang berkaitan dengan hyperspace, dan Tesla. Kalau ini sudah kita sadari kita akan sadar betul apa yang harus kita siapkan."31

Mempersiapkan Sumber Daya Manusia adalah hal yang harus dilakukan agar bisa mengantisipasi era revolusi industri 4.0 itulah yang dikatakan Bapak Joko Widodo. Namun, Bapak Joko Widodo lupa mengatakan untuk mempersiapkan SDM itu dibarengi dengan persiapan mempertebal keimanan. Persaingan dalam dunia perindustrian akan semakin ketat dan tingkat strespun akan meningkat. Maka perlu bagi manusia yang akan bergabung dan bersaing pada dunia industri agar mempertebal keimanan serta menjunjung moralitas yang tinggi sehingga tidak terjadi hal-hal yang tidak diinginkan.

Mengutip dari buku Imam Syafi'ie yang berjudul "Konsep Ilmu Pengetahuan dalam Al-Qur'an", seorang ilmuwan di bidang hubungan internasional Marwah Daud Ibrahim mengatakan terdapat tiga hal yang seharusnya menjadi fokus perhatian oleh ilmuwan yang hendak mengembangkan sains sekaligus penggunaannya. Pertama, pengembangan ilmu pengetahuan memerlukan kerendahan hati. Kedua, orientasi dan pengembangan sains dan teknologi membutuhkan solidaritas. Ketiga, orientasi dan pengembangan sains dan teknologi membutuhkan kerjasama antara agamawan dan ilmuwan. ${ }^{32}$

30 Ray Jordan, “Jokowi Minta Wali Kota Siapkan SDM Hadapi Revolusi Industri 4.0', Artikel Berita," http://m.detik.com, Oktober 2018.

31 Jordan.

${ }^{32}$ Syafi'ie, “Konsep Ilmu Pengetahuan dalam al-Qur'an", hlm. 148. 
Apa yang disampaikan oleh Marwah Daud Ibrahim ini adalah apa yang diinginkan oleh al-Qur'an dan Pancasila dalam perkembangan era digital dan industri. Menghadirkan kerendahan hati dalam pengembangan ilmu pengetahuan berimplikasi pada tidak hilangnya eksistensi manusia. Meskipun teknologi itu berjalan secara independen maupun dikoordinasi manusia, ia tidak akan membuat manusia kehilangan eksistensi, karena pada hakikatnya teknologi itu ada karena pemikiran manusia. Menghadirkan solidaritas dalam pengembangan ilmu pengetahuan dan teknologi berimplikasi pada pemikiran untuk mengembangkannya demi kesatuan dan kemudahan manusia, bukan karena motif pribadi atau kelompok. Selanjutnya, kerjasama antara ilmuwan dan agamawan akan menjadikan perkembangan ilmu pengetahuan akan berjalan lurus demi kebahagiaan dunia dan akhirat. Agamawan akan mengontrol perkembangan ilmu pengetahuan yang bertentangan dengan nilai-nilai universal alQur'an dan nilai-nilai Pancasila.

Adapun nilai-nilai Pancasila yang bisa dijadikan landasan moral bagi era revolusi indutri 4.0 adalah nilai ketuhanan, kemanusiaan, persatuan, kerakyatan, dan keadilan. Dalam mengembangkan era digital dan industri, dengan mengamalkan kelima sila tersebut akan mengarahkan manusia menuju peradaban yang lebih baik dan lebih maju lagi. Sila pertama akan mengingatkan manusia selalu akan kehadiran Tuhan, sehingga tidak ingin berbuat sesuatu yang membuat marahnya Tuhan. Sila kedua akan memanusiawikan manusia sebagai manusia yang adil dan beradab dan tentunya ia juga akan memanusiawikan dan memberi nilai moral pada era digital dan industri.

Sila ketiga mengingatkan manusia akan indahnya sebuah persatuan, perbedaan bukan dijadikan sebuah permusuhan namun perekat perbedaan. Maka, di dalam dunia perindustrian tidak akan ada yang namanya permusuhan karena perbedaan skill, antara high skill dan low skill. Sila keempat akan menyadarkan manusia terhadap jati dirinya sebagai rakyat Indonesia yang memiliki nilainilai kebijaksanaan dan permusyawaratan untuk mencapai mufakat, ini akan berimplikasi pada hadirnya rasa saling menghargai dikalangan pelaku industri. Sila terakhir akan mengantarkan manusia untuk berlaku adil. Pemegang saham 
dalam industri tidak akan berpikir untuk memperkaya dirinya sendiri. Pembagian upah akan berjalan sesuai dengan kemampuan si pekerja industri, dan ini tentunya akan melahirkan kesejahteraan dan hilangnya kesenjangan ekonomi.

\section{E. Kesimpulan}

Berdasarkan pembahasan di atas dapat disimpulkan bahwa: penyebab kemunduran moral era revolusi industri 4.0 yaitu pertama, para pencipta dan pengembang teknologi menciptakan ilmu pengetahuan itu bebas nilai. Akibatnya, mereka freedom dalam penelitian dan percobaan meskipun hal tersebut bisa membawa kepada jatuhnya moral values dan humanity. Kedua, kebahagiaan tertinggi yang dianggap berasal dari materi sehingga menjadikan manusia melakukan apa saja untuk mendapatkannya, termasuk cara-cara yang kurang halal agar bisa memperbanyak pundi-pundi keuangannya. Adapun kontribusi al-Qur'an dan Pancasila terhadap era revolusi industri 4.0 menjadikan perkembangannya era revolusi industri 4.0 sarat akan nilai moralitas dan kemanusiaan. Al-Qur'an dan Pancasila akan mengontrol sekaligus menjadi ukuran baik dan buruk dalam perkembangannya. Setiap yang terlibat di dalam era revolusi industri 4.0 baik pelaku industri maupun teknologinya akan terikat dengan nilai-nilai al-Qur'an dan Pancasila. Terikat di sini artinya bukan berarti tidak memberikan kebebasan dalam perkembangan era revolusi industri 4.0. Hanya saja, tidak memberikan luang akan perkembangannya yang melenceng dari tujuan ia diciptakan yaitu untuk kemudahan di dunia dan sebagai sarana menuju kebahagiaan hakiki di akhirat kelak.

\section{DAFTAR PUSTAKA}

Baiquni, Ahmad. "Al-Qur'an dan Ilmu Pengetahuan Kealaman". Jakarta: Dana Bhakti Prima Yasa, 1996. 
Daman, Rozikin. "Pancasila: Dasar Falsafah Negara". Jakarta: PT Raja Grafindo Persada, 1995.

Hasan, M. Iqbal. "Pokok-Pokok Materi Metodologi Penelitian dan Aplikasinya". Jakarta: Ghalia Indonesia, 2002.

Jordan, Ray. "Jokowi Minta Wali Kota Siapkan SDM Hadapi Revolusi Industri 4.0', Artikel Berita.” http://m.detik.com, Oktober 2018.

Kaelan. "Filsafat Pancasila". Yogyakarta: Paradigma, 1996.

—. Metodologi Kualitatif Bidang Filsafat. Yogyakarta: Pramadina, 2005.

Kuntowijoyo. "Demokrasi dan Budaya Birokrasi". Yogyakarta: Benteng Budaya, 1994.

Nasution, Harun. "Muhammad Abduh dan Teologi Rasional Mu'tazilah". Jakarta: UI Press, 1987.

Prasetyo, Hoedi, dan Wahyudi Sutopo. "Industri 4.0: Telaah Klasifikasi Aspek dan Arah Perkembangan Riset.” J@ti Undip Jurnal Teknik Industri, Januari, Vol. 13, no. 1 (2018).

. "Perkembangan Keilmuan Teknik Industri Menuju Era Industri 4.0, Seminar dan Konferensi Nasional IDEC 2017." http://idec.industri.ft.uns.ac.id, 30 September 2018.

Rosyadi, Slamet. "Revolusi Industri 4.0: Peluang dan Tantangan bagi Alumni Universitas Terbuka." http://researchgate.net/publication/, 30 September 2018.

Satya, Venti Eka. "Strategi Indonesia Menghadapi Industri 4.0." Info Singkat, Mei, Vol. 10, no. 09/1/Puslit, (2018).

Shihab, M. Quraish. "Membumikan al-Qur'an". Jilid. 2. Jakarta: Lentera Hati, 2012.

. "Tafsir al-Mishbah: Pesan, Kesan dan Keserasian alQur'an". Vol. 15. Jakarta: Lentera Hati, 2002.

Sudarto. "Metodologi Penelitian Filsafat". Cet. 3. Jakarta: PT Raja Grafindo Persada, 2002.

Sudaryanto. "Filsafat Politik Pancasila: Refleksi atas Teks Perumusan Pancasila". Yogyakarta: Kepel Press, 2007.

Suwardana, Hendra. "Revolusi Industri 4.0 Berbasis Revolusi Mental." Jurnal Jati Unik, Vol. 1, no. 2 (2017). 
Syafi'ie, Imam. "Konsep Ilmu Pengetahuan dalam al-Qur'an". Yogyakarta: UII Press, 2000.

Ulya. "Berbagai Pendekatan dalam Studi al-Qur'an: Penggunaan Ilmu-ilmu Sosial, Humaniora dan Kebahasaan dalam Penafsiran al-Qur'an". Yogyakarta: Idea Press, 2017.

Wardhana, Wisnu Arya. "Al-Qur'an dan Energi Nuklir". Yogyakarta: Pustaka Pelajar, 2004.

Yahya, Muhammad. “"Era Industri 4.0: Tantangan dan Peluang Perkembangan Pendidikan Kejuruan Indonesia', Pidato Pengukuhan dalam penerimaan Jabatan Profesor Universita Negeri Makassar." http://eprints.unm.ac.id, 14 Maret 2018. 